\title{
QUEEN'S
UNIVERSITY
BELFAST
}

\section{The Ocho Poetas Mexicanos and the marginalisation of Catholic authors in post-revolutionary Mexico}

Bowskill, S. (2015). The Ocho Poetas Mexicanos and the marginalisation of Catholic authors in postrevolutionary Mexico. Journal of Iberian and Latin American Studies, 21(2), 89-106.

https://doi.org/10.1080/14701847.2015.1144305

Published in:

Journal of Iberian and Latin American Studies

Document Version:

Peer reviewed version

Queen's University Belfast - Research Portal:

Link to publication record in Queen's University Belfast Research Portal

Publisher rights

Copyright 2016 Taylor and Francis.

This is an Accepted Manuscript of an article published by Taylor \& Francis in

Journal of Iberian and Latin American Studies in 2015 available online: http://www.tandfonline.com/doi/full/10.1080/14701847.2015.1144305

\section{General rights}

Copyright for the publications made accessible via the Queen's University Belfast Research Portal is retained by the author(s) and / or other copyright owners and it is a condition of accessing these publications that users recognise and abide by the legal requirements associated with these rights.

Take down policy

The Research Portal is Queen's institutional repository that provides access to Queen's research output. Every effort has been made to ensure that content in the Research Portal does not infringe any person's rights, or applicable UK laws. If you discover content in the Research Portal that you believe breaches copyright or violates any law, please contact openaccess@qub.ac.uk. 


\title{
The Ocho poetas mexicanos and the marginalisation of Catholic authors in post- revolutionary Mexico
}

\section{Sarah Bowskill}

School of Modern Languages, Queen's University, Belfast

\begin{abstract}
The group known as the Ocho poetas mexicanos were marginalised in postrevolutionary literary circles and remain largely forgotten by literary history because they were dismissed as Catholic authors by a literary establishment which favoured nation-building literature at a time when Catholicism was excluded from official constructions of nationhood. This article draws attention to the significant contribution made by group members to contemporary cultural life and reevaluates the work they published in the 1955 anthology which announced their arrival onto the literary scene. An analysis of this collection demonstrates that there was scant justification within their poetry for labelling all group members as Catholic poets and suggests that as a collective they are best understood with reference to the "universal" strand of Mexican literature and as heirs to groups such as the Contemporáneos. The treatment of the Ocho poetas provides important evidence of the way in which Catholic authors were marginalised in mid-twentieth century Mexico, even if they did not express religious beliefs in their work, and draws attention to the non-literary criteria which can come into play when evaluating texts.
\end{abstract}

Keywords: Mexican poetry; religion and literature; canon formation; Ocho poetas; Alejandro Avilés; Roberto Cabral del Hoyo; Dolores Castro; Rosario Castellanos; Efrén Hernández; Honorato Ignacio Magaloni; Octavio Novaro; Javier Peñalosa

The group known as the Ocho poetas mexicanos, comprising Alejandro Avilés (1915-

2005), Roberto Cabral del Hoyo (1913-1999), Rosario Castellanos (1925-1974), Dolores

Castro (b.1923), Efrén Hernández (1904-1958), Honorato Ignacio Magaloni (1898-1974),

Octavio Novaro (1910-1991) and Javier Peñalosa (1921-1977), announced its arrival onto

the literary scene with the publication of an anthology of poetry in 1955 entitled Ocho

poetas mexicanos. Years later, in a newspaper review of Castro's collection of poetry El corazón transfigurado (1949), critic Juan Cervera (CNL) praised the anthology as “aquella antología que ha hecho historia” and expressed regret that it had never been 
reprinted: “seguimos inútilmente esperando su reedición, lo que es, sin duda, lamentable por lo valioso de este libro.” Cervera's comments suggest that the Ocho poetas mexicanos anthology had some merit but, with only 1400 copies ever printed, it never reached a sufficiently wide audience to have a real impact on the careers of its contributors. Perhaps more significant than the anthology's limited print run in determining the fate of these poets, however, was the fact that, shortly after its publication, the group was labelled "los ocho poetas católicos.” As a result, group members found themselves excluded from mainstream literary circles.

The group has been largely overlooked by literary historians and group members have received scant critical attention. To date, the only study of the group has been an undergraduate dissertation by Porfirio Murguía Luna (1993). There is now a substantial body of work on Castellanos, but she was recovered only later by feminist criticism in the 1970s and her membership of the Ocho poetas is often overlooked. The short stories of Efrén Hernández have received some attention, including a book-length study by Mary M. Harmon (1972) and an article by John Brushwood (1988), while Benjamín Barajas (2004, 2010, accessed 2011) has published on Dolores Castro’s poetry. Criticism about the other poets is limited to prefaces in editions of their poetry. All of the poets have entries in what is perhaps the most authoritative history of Mexican literature, the Diccionario de escritores mexicanos siglo $X X$ edited by Aurora M. Ocampo (Ocampo 1988, 1997; see also Navarrete Maya 1988, 2002; Olivares Zorilla and Pereira 1988; Ortiz Flores 2000; Rubio Pacho 2000, 2002; and Sánchez Rebolledo 1988), although they are often brief and lack any detail of the poets' involvement in the Ocho poetas group. 
mentioned at all, and, in the case of the other poets, only a sentence is given stating that they were associated with the group along with a list of the other members. Given the lack of existing criticism, this article draws extensively on my 2009 interview with the last surviving member of the group, Dolores Castro. It also uses newspaper articles, reviews and interviews from the archive of the Centro Nacional de Literatura (CNL) in Mexico City as well as reports of recent events organised in their honour in order to tell their story. ${ }^{\mathrm{i}}$

This article outlines the context which led to the marginalisation of Catholic authors in post-revolutionary Mexico before re-evaluating the contribution of the Ocho poetas to Mexican literature. An analysis of the poetry in the anthology explores the question of whether the label of "Catholic poets" was warranted on the basis of their work, or if the label was the result of extra-literary factors. It argues that, while some members were Catholic, as a group, and in their poetry, the Ocho poetas mexicanos were less concerned with religion and more interested in nature and love, and so are best understood with reference to the "universal" strand of Mexican literature. This strand, which was criticised for prioritising aesthetics over national politics, can be traced from the Ateneo de la Juventud to the Contemporáneos and Taller groups and, via the Ocho poetas, to the Generación del 50. This is the less frequently told history of Mexican literature.

\section{Marginalisation}

Both the "universal" and Catholic literary traditions to which the Ocho poetas belonged were in contradistinction to the nation-building literature about lo mexicano and mexicanidad, which was preferred by the post-revolutionary cultural elite. The perception 
that the Catholic Church had supported the opposing side during the Revolution, led by Victoriano Huerta, meant that Catholicism did not form part of the official constructions of post-revolutionary nationhood. Tensions were further aggravated as a result of the Cristero wars (1926-29; 1934-36) which followed the break down in Church-State relations. In the literary sphere, pro-Cristero novels which supported the Church did not accord with the requirements and expectations of official culture, exemplified by the novels of the Mexican Revolution, and so were rejected by the literary establishment (Ruiz Abreu 2003, 22). Pro-Cristero literature was marginalised because of its supposedly anti-revolutionary content. However, the experience of the Ocho poetas mexicanos indicates that if authors in post-revolutionary Mexico were Catholic, or even if they were perceived to be so, they could also be marginalised. This follows Alvaro Ruiz Abreu's assessment that, even decades after the Cristero wars were over, it was difficult to be taken seriously in the intellectual and cultural milieu in Mexico if one were Catholic: “durante muchas décadas, y hasta fechas muy recientes, declararse católico en el ámbito intelectual en México era una ironía, tenía un claro carácter peyorativo: equivalía a ser un conservador a ultranza, un ser extraño en un país 'revolucionario', colocarse a un lado de la historia, el progreso y lo moderno” (Ruiz Abreu 2003, 18).

One of the main reasons why the Ocho poetas came to be known as Catholic poets was because of their association with the magazine Ábside and Alfonso Méndez Plancarte (1909-1955). Méndez Plancarte was an ordained priest and Ábside "en su larga existencia constituyó la expresión más acabada de la cultura católica mexicana” (Rubio Pacho 2000, 24). According to Cabral del Hoyo, between 1950 and 1956, the eight poets met every Saturday, along with Méndez Plancarte, “en una especie de taller de poesía” (La Jornada 
Semanal, October 4, 2004). Occasionally, they were joined by other authors: Castro recalled the presence of Guadalupe Dueñas and Raúl Navarrete; Cabral del Hoyo remembered Elías Nandino, Carlos Pellicer, José Gorostiza and Salvador Novo participating (El Angel Cultural supl. de [why in Spanish?] Reforma, October 17, 1999); and Uriel Martínez added Juan Bañuelos, José Gorostiza and José Revueltas to the list of Commented [SB2]: Could be in English - supplement of - but seems more logical in Spanish given that the title of the publication is Spanish. Simmilarly two lines below - La Jornada secc. Cultura instead of La Jornada. Cultura section.

Castro explained that the group "se formó en torno de un gran hombre que es Alejandro Avilés.” At the time, Avilés was responsible for a series of interviews called “Poetas mayores” published in the newspaper El Universal. The series was well received and Castro described how it captured the state of contemporary Mexican poetry:

de todos los [poetas] que [Avilés] entrevistó habrá tres que no siguieron publicando y otros que fueron tan importantes como José Gorostiza, como los de la revista Contemporáneos. Casi a todos él los entrevistó, los que estaban vivos. Y entrevistó también a Jaime Sabines y a otros poetas del momento, a Efrén Hernández, que es un poeta que no es muy conocido pero que es muy buen poeta y al resto de los ocho.

Although Castro stated that the group formed around Avilés, there are different opinions about how it came into existence and where the idea for the publication of the anthology originated. In an interview in El Universal, Avilés explained that the idea for the anthology came from Méndez Plancarte: “nosotros nos reuníamos cada ocho días e intercambiábamos nuestras experiencias literarias hasta que un día el director de la revista Ábside, Alfonso Méndez Plancarte, se interesó por nuestro trabajo y editó una antología poética titulada Ocho Poetas” (El Universal, September 5, 1984). In a later interview with Gerardo Ochoa Sandy, Avilés further indicated that it was Méndez Plancarte who had first suggested organising a tertulia (Proceso, July 8, 1991). Cabral del Hoyo has speculated that Avilés may have received advice from Méndez Plancarte as to which 
poets to select for the group from the forty or fifty that Avilés had interviewed for his column in El Universal (Cultura Sur, October-December, 1995). Cabral del Hoyo, therefore, suggests that Avilés and Méndez Plancarte had made a conscious decision to form a select group of poets. The criteria that were used to select group members are, however, uncertain. Nonetheless, Cabral del Hoyo in La Jornada Semanal (October 4, 2004) noted that “[e]n el fondo Méndez Plancarte quería que fuéramos 'poetas católicos’” even though not all group members were Catholic (Proceso, July 8, 1991). Indeed, the group rejected the idea of including a prologue to the anthology written by Méndez Plancarte, presumably because of reservations about its content and the consequences that such a clear endorsement by Méndez Plancarte might have for them. In hindsight, such reservations were well founded as their association with Méndez Plancarte appears to have damaged the prospects of these young poets. According to Cabral del Hoyo, “[a]l grupo Ocho poetas mexicanos nos perjudicó que el primer libro saliera bajo el signo de Ábside, una revista-editorial digamos confesional, dirigida por sacerdotes. Gente como Efraín Huerta, sin pensarlo, decía: 'Esos son mochos, publicaron en Ábside, son curas, curas destripados, beatos’. Eso decían, a pesar de que éramos absolutamente laicos” (Proceso, July 8, 1991).

Ocho poetas was published by Editorial Jus and the printer's mark at the end of the anthology concludes "Laus Deo." The decision to publish with Jus may be another factor that led to the understanding that the group was Catholic. Although Jus was better known for publishing books about Law and philosophy rather than poetry, the publishing house was also renowned for publishing much Cristero literature (Ruiz Abreu 2003, 25). For this reason, José Francisco Conde Ortega pointed out that, following the publication 
of the anthology, the group came to be known as "los 8PC: los ocho poetas católicos" (Crónica Dominical, October 24, 1999). The perception of the group as "poetas católicos" seems to have gained currency in the years following the publication of the anthology, as poems by Peñalosa, Novaro, Hernández, Castellanos, Avilés and Cabral del Hoyo were included in Carlos González Salas’ Antología mexicana de poesía religiosa (1960). Their reputation as Catholic poets also had longevity. A 1994 review of Avilés’ collected works in El Universal noted that he belonged to "esa vasta corriente de artistas e intelectuales creyentes que en nuestro país han sido sistemáticamente ignorados por las instituciones, porque la oficialidad cultural continúa siendo groseramente laica” (El Universal, October 27, 1994). Also, in 2003, Édgar Córdova referred to the group to which Castro belonged as “Ocho poetas católicos” (Milenio, April 13, 2003).

Their (perceived) Catholicism combined with their association with Méndez Plancarte and Jus meant that the poets were marginalised and struggled to get their work published, a problem which Castro acknowledged in an interview with Barajas (2004, 14). A few years before his death, Cabral del Hoyo was interviewed by La Jornada Semanal. In this interview he was asked about "el sambenito de poetas confesionales con que se les borró del mapa literario de la época.” In response, he acknowledged that the anthology was well intentioned, but that

a la postre acabó perjudicándonos, pues críticos de izquierda se apresuraron a calificarnos de sectarios, aunque en realidad Magaloni y Novaro eran bon vivants, Avilés y Peñalosa católicos, Rosario librepensadora y Hernández y yo agnósticos sin fanatismos. Bueno, pues se trató de un sambenito que impidió un seguimiento más objetivo de la obra literaria respectiva. (La Jornada Semanal, October 4, 2004)

Dolores Castro has likewise spoken of the ideological differences within the group: "Lo que pasa es que cada quien tenía una manera de pensar totalmente distinta.” She 
explained that she and her husband were Catholic but from a liberal tradition which stemmed from liberation theology. In contrast, Novaro had lost his faith and Hernández was agnostic. Magaloni was, according to Castro, particularly interested in Mayan culture. Castro recalled that Castellanos often changed her mind about religion: "Ella al rato era católica, que seguía con todo hasta con el ayuno de la cuaresma y todo, y de pronto ya no creía en nada.” ${ }^{\mathrm{ii}}$ As well as having different attitudes towards religion, the group members came from across the political spectrum. Avilés was an active member of the Partido Acción Nacional (PAN) and between 1948 and 1963 was in charge of the party newspaper La Nación, while Novaro, inspired by Cardenista politics, founded schools in Mexico City and Yucatan (Reforma, September 20, 2005). ${ }^{\text {iii }}$ Castro and her husband had taken part in the events of 1968 at which time Peñalosa was working for the newspaper Excélsior.

Newspaper articles provide evidence that even those group members who did hold religious beliefs tried to keep their writing separate from their religious affiliations. In an article by Jorge Luis Berdeja in El Universal published in November 1994, Avilés is quoted as saying that, although he was Catholic, he preferred not to use poetry as a vehicle for promoting religion: “yo no tengo muchos poemas explícitamente religiosos, porque creo que se ha abusado mucho de ello, y que se han escrito muchos poemitas piadosos que tienen tema religioso, pero que no son religiosos. Creo que la divinidad es el tema más difícil, delicado y digno de respeto, por eso no se debe abusar de él.” Castro similarly rejected the use of poetry for the purpose of propaganda, be it political or religious: "En cuanto a propaganda religiosa, creo que cuando se hace falsificada en poesía, es mil veces peor que la propaganda política. Porque creo que si bien no todo
Commented [SB3]: The numbering in the main text (ii) is different to that in the notes (2). Is that correct? 
religioso es poeta, sí todo poeta es religioso. La religiosidad poética es tan respetable, que cuando se da falsificada es verdaderamente imperdonable” (Avilés 1996, 10).

The Ocho poetas appear to have suffered because some of them were Catholic and because of their association with Méndez Plancarte, Ábside and Jus. In addition, the group did not have, and did not seek to foster, ties with the nationalist cultural elite which “dominated cultural production through their monopoly of popular and elite media” (Cohn 2005, 142). Furthermore, their work was not seen as addressing the issues of $l o$ mexicano and mexicanidad with which the official culture was preoccupied. Speaking after Novaro’s funeral, Ricardo Cortés Tamayo blamed the literary establishment for Novaro’s marginalisation as a poet: “Pese a todos los silencios que se hicieron alrededor de Octavio Novaro por parte de esos grupos que se creen factótum literario en México, hacedores de la gloria o del fracaso de los escritores mexicanos, él fue un poeta verdadero” (cited in González Garduño 1991, CNL). Beatriz Gonzalez Garduño, however, cites another article by Cortés Tamayo in which he admitted that Novaro did not use the opportunities for publicity that were available to him but instead remained “fiel a la sinceridad profunda de su ser poeta” (1991, CNL). Following the death of Cabral del Hoyo in 1999, Héctor de Mauleón, in an article published in Crónica, gave a very frank account of how the Ocho poetas came to be marginalised because of their association with Méndez Plancarte and Ábside. Nonetheless, he also conceded that fame was never a priority for the group: “Al menos durante el tiempo que duró su tertulia, nunca les interesó la fama: no asistían a cócteles ni a presentaciones de libros, no pedían reseñas favorables a los amigos ni se hacían publicidad” (Crónica, October 5, 1999). Indeed, there is ample evidence to suggest that the Ocho poetas were not well known in 
Mexico because they did not seek out opportunities for publicity at a time when authors were increasingly professionalized. Castro exemplifies this tendency. Pacheco notes that Castro has been overshadowed by Castellanos, but argues that the quality of her work stands out "pese a su voluntario alejamiento" $(1965,215)$. Castro acknowledged that she preferred to dedicate herself to her children instead of going to cocktail parties or seeking government grants and posts:

Yo tuve empleos muy modestos en educación, en el seguro pero nunca, nunca estuve cerca de los jefes de nada. Luego pues me casé, tuve siete hijos, entonces qué tiempo puede haber para andar en socialité. Yo lo que tenía que hacer era escribir, leer y atender a mis hijos. Como los atendí, quién sabe bien o mal, pero no dejé de escribir, eso sí.

Although there is no way to tell whether the Ocho poetas would have been accepted if they had sought out greater publicity in the literary sphere, it is clear that the decision on the part of some of the group not to participate in self-promotion or networking affected how they were received.

\section{Cultural and political contributions}

Even though they were not part of the literary establishment, the Ocho poetas made significant contributions to the cultural life of Mexico. Perhaps the most important undertaking associated with the group was the literary magazine América. Revista Antológica, which Hernández co-directed with Marco Antonio Millán. América was published by the Secretaría de Educación Pública (SEP) over a period of about five years in the 1940s, although Millán characterised it as only semi-official (Sábado supl. de [why in Spanish? See above] Unomásuno, July 4, 1987; Excélsior, August 19, 1984).

According to Lourdes Franco Bagnouls, América was "uno de los eslabones más 
transcendentes en la larga cadena de consolidación de la literatura mexicana” ( $\mathrm{La}$ Jornada, March 1, 2004). Initially, the magazine focused on politics but "se transformó en revista eminentemente literaria, abierta a la gente nueva y valiosa, ajena a los grupos de poder y, por tanto, poco valorada en el ámbito de la crítica” (Sábado supl. de [ditto] Commented [SB5]: lower case d Unomásuno, July 4, 1987). The importance of this open forum was also highligthed by Pacheco: "La revista América siguió la política de puertas abiertas que un siglo atrás recomendó Altamirano para el desarrollo de la literatura nacional” (1965, 214). Pacheco’s assessment provides evidence of the valuable work that the Ocho poetas undertook at the margins of literary culture, and, as a result of its open editorial policy, América was responsible for publishing the writings of emerging authors who later came to the forefront of Mexican literature, often as part of the Generación del 50. Among those whose work was published in the magazine are: Rosario Castellanos, Sergio Magaña, Jaime Sabines, Emilio Carballido, Luisa Josefina Hernández and Bonifaz Nuño. Hernández was also responsible for encouraging the talent of Juan Rulfo, and América was the first to publish his short stories and photographs. The importance of Hernández's role in the development of Rulfo’s career was recognised by Jorge Ricardo who described Hernández as “el padre editorial de Rulfo” (Reforma, January 30, 2008). Furthermore, Luis Leal has asserted that “[s]in la presencia de Hernández es imposible explicar las dos obras de Rulfo” (cited in Murad 1977-8, 58).

Another major achievement associated with the Ocho poetas was the publishing house Editorial Novaro, which Octavio Novaro established with his brother in the 1950s and which "transformó totalmente el negocio de revistas en el país” because it was "el primer emporio de este tipo, elaborado con capital totalmente mexicano” (Novaro cited in 
Rosales y Zamora 1987, CNL). The business was so successful that it became "una transnacional que vendió a todo el mundo de habla hispana. Tan sólo nuestra casa llegó a representar el 3.5 de la exportación total del país” (Novaro cited in Rosales y Zamora 1987, CNL). Novaro was also extensively involved with the newspaper industry: he cofounded El Popular; edited Prensa Gráfica, La Prensa and the magazine Clarín; and wrote for El Universal, Novedades and El Día (El Universal, May 7, 1991). Similarly, Javier Peñalosa contributed to a range of newspapers and cultural magazines. Of particular note, according to Carlos Rubio Pacho (2002, 437), were his columns in the “México en la Cultura" supplement of Novedades and his "5 noticias literarias importantes del mes en México,” later called “Los hechos y la cultura en México,” in the magazine Nivel. As an authority on pre-Hispanic and Mayan culture, Magaloni founded the magazine Poesía de América, which was sponsored by Cuadernos Americanos (Ortiz Flores 2000, 11). Castellanos was a journalist, too, and contributed to the editorial pages of Excélsior from 1962 until her death (El Universal, September 13, 1974). Avilés wrote for newspapers including Diario de México, La Voz de Michoacán, Excélsior, El Universal and the magazines Señal, América and Proceso. In addition, he was the headmaster of the Escuela de Periodismo Carlos Septién García and was responsible for training the next generation of writers and journalists (Excélsior, June 4, 2000; July 22, 1992). Peñalosa and Castro were teachers at a school which was established with the support of Acción Católica Mexicana and the PAN, but which was later secularised and made non-partisan by Avilés so that it could be recognised by the SEP and be allowed to award degrees (Excélsior, July 22, 1992; Reforma, September 20, 2005). 
The important role radio played in spreading Mexican culture has been recognised by Joy Elizabeth Hayes (2000), and several of the Ocho poetas were involved in the early days of this medium. Cabral del Hoyo worked for Radio XEQ, Radio Hispanoamericana, the station XEBZ, Radio Mil and, at the request of Rafael F. Muñoz, the SEP's Radio Educación (Excélsior, October 22, 1988; La Jornada Semanal, October 4, 2004). Avilés founded and directed the cultural news programme on the XELA radio station and, acting as director periodístico at the Agencia Mexicana de Servicios Informativos, he helped to pioneer radio news provision (Reforma, September 20, 2005). Together with Castro, he presented the television programme Poetas de México on Channel 11 ("Nota biográfica," CNL). As well as working with Avilés on this programme for three years, Castro worked for Radio Femenina and Radio UNAM. ${ }^{\text {iv }}$ She described the vibrant atmosphere that existed during her time at the station when she had the opportunity to meet and interview emerging Mexican authors as well as many who were in exile from Spain and other Latin American countries, including Ernesto Cardenal, Ernesto Mejía Sánchez, Tito Monterroso, Héctor Raúl González, Jaime Sabines and Emilio Carballido.

Cabral del Hoyo, Avilés, Novaro and Castellanos were also active in political life. While Avilés was influential in the opposition PAN Party, Castellanos held a number of government posts and was appointed ambassador to Israel in 1971 during Luis Echeverría’s presidency. Novaro was ambassador to Switzerland under President Adolfo López Mateos, on whose election campaign Cabral del Hoyo worked. Afterwards, Cabral del Hoyo was appointed to a position in the Departamento de Turismo which López Mateos had created (Rosales y Zamora 1987, CNL; La Jornada Semanal, October 4, 2004). Under Díaz Ordaz, he was given a post as director of Advertising and Public 
Relations for the Fondo de Cultura Económica (La Jornada Semanal, October 4, 2004). In this role, he produced the first catalogue of the FCE with over seven-thousand bibliographical notes (El Nacional, April 10, 1993). Significantly, then, the Ocho poetas were not an isolated and self-contained group and even if they did not always go out of their way to promote their own work, they were actively engaged with the cultural and political life of Mexico through their chosen careers.

\section{Mexican literature with a "universal” outlook}

Despite the numerous and wide-ranging contributions that the Ocho poetas made to the cultural and political milieu of mid-century Mexico they remained at the margins of the literary establishment. While their exclusion from the cultural elite may be attributed to their lack of self-promotion, their religious beliefs, or personal friendships, it may also have to do with their mode of poetic expression, which was more in keeping with the “universal” strand of Mexican literature. According to Avilés, the group’s name was originally "una ocurrencia humorística, adoptada un poco en plan de reto frente a la poesía oficial de entonces," which was later adopted for the title of the anthology (Diorama de la Cultura, October 11, 1974). Several group members had connections to the Contemporáneos group which, from the late 1920s onwards, advocated a more outward looking Mexican literature. Through his work in the Departamento Editorial of the SEP, Hernández knew Xavier Villaurrutia and Salvador Novo, two of the leading members of the Contemporáneos group (Toledo 2007, 9; Unomásuno, August 1, 1998). Indeed, John Brushwood (1988, 90) has noted the influence of the Contemporáneos' ideas on Hernández's short stories. Salvador Oropesa claims that, "Novo and the 
Contemporáneos group wanted a Mexican literature open to the beneficial influences of foreign ideas even if, on occasion, they attacked these ideas” $(2003,11)$. This outlook brought the Contemporáneos into conflict with the nationalists and the nationalisitic Estridentista group. In addition, Hernández and Octavio Paz were involved with the magazine Taller, which, in Murad's opinion, was “una prolongación de las ideas culturales y estéticas” of the Contemporáneos group, although he notes that Paz and Efraín Huerta also "brought certain social and political concerns to the journal” (1977-78, 61). Pacheco $(1965,213)$ has suggested that the poets of Taller may have been overshadowed by Paz, and this might explain why the association between the Ocho poetas and the Contemporáneos has been overlooked. In light of this connection, there should be a re-evaluation of the Ocho poetas' place in Mexican literary history as heirs to the Contemporáneos and Taller groups, and as precursors to the Generación del 50.

The poetry of the Ocho poetas did not obviously address issues of lo mexicano or mexicanidad, which were in vogue after the Revolution. When the group met, they read "poesía universal” and were preoccupied with poetry as language, "poesía como verbo,” rather than as a means of narrating events. At a time when the cultural and political elite valued literature that contributed to nation-building, the preferences of the Ocho poetas frequently led to them being described as outdated. For instance, Héctor de Mauleón observed that Cabral del Hoyo was “a contrapelo del espíritu de la época, practicó como poeta las formas clásicas: de la décima a la octava, de la lira al romance, y de ahí al soneto” (Crónica, October 5, 1995). Novaro recalled that Hernández’s poetry was considered "arcaísta" by some of his contemporaries and Marco Antonio Millán pointed out its "ecos románticos muy acentuados" which may have been deemed unfashionable at 
the time (Sábado supl. de [see above] Unomásuno, July 4, 1987). Emmauel Carballo went so far as to admit that he did not initially appreciate the significance of Hernández’s style of poetry: "fue necesario que transcurrieran varios años para que me diera cuenta de que para entenderlo y gozarlo era preciso seguir un camino diferente: olvidar las modas y adentrarse en su obra sin ideas preconcebidas” (Sábado, August 1, 1998). Francisco Zendejas, an established reviewer of Excélsior, observed that Novaro’s poetry was unlike anything else from the 1960s and 70s (December 14, 1983). Thus, the Ocho poetas appear to have been marginalised not only because of their perceived Catholic partisanship and their failure to promote themselves, but also because their poetry did not fit in with the dominant literary trends of their day. As their choice of name for the group makes clear, they saw themselves as producing Mexican literature but their brand of "national" literature was not the one endorsed by the cultural elites of the time.

The Ocho poetas began to receive greater recognition from the mid-1980s onwards, which may reflect changing attitudes to Catholicism in literary and political circles. $^{\mathrm{v}}$ Numerous homenajes have been held in their honour arranged by local and national organisations, including the Instituto Nacional de Bellas Artes (INBA), and some of the group members have received prizes and awards. Much of their work is now available again having been published in their collected works, sometimes by prestigious publishers such as the Fondo de Cultura Económica. There have also been numerous newspaper and magazine articles recognising their influence and achievements. It should be noted, however, that this recognition is for individual poets and not for the group as a whole. Perhaps this is because no-one has identified the common style or theme in their poetry which would unify them from a literary perspective. When asked what, if 
anything, the group had in common, Castro indicated that the group was united by a shared interest in poetry: “¿Cuál era, digamos, el centro que nos unía? La poesía nada más. Todos estábamos escribiendo poesía y queríamos seguir escribiendo poesía, hacer una antología buena de la poesía mexicana, leer poesía universal, etc.” In Cultura Sur, Cabral del Hoyo similarly reported that the group were "hermanados por nuestra vocación literaria" and wrote of how, at their gatherings, "leíamos poesía y la criticábamos; nos mostrábamos lo nuevo que hubiéramos escrito, y en un ambiente de auténtica amistad en el que jamás enseñó la envidia su rostro avinagrado, permanecimos reuniéndonos así durante cosa de seis años” (October-December, 1995). In 1974, Avilés summed up the connection between the group members: "La honda fraternidad nos unía, la ausencia absoluta de emulación 'profesional', la coincidencia de 'los ocho' en concebir la poesía como verbo, se expresó en el epígrafe común escrito por Dolores: ‘Cada uno su lengua, todos en una llama”" (Diorama de la Cultura, October 11, 1974). One way to interpret the poets' assertions is that they shared an interest in poetry but not a common theme or perspective. However, it is equally possible to see their emphasis on poetry as being of paramount importance as part of their vision for an alternative "Mexican" literature which would prioritise aesthetic rather than political concerns, and which would be Mexican in inspiration yet universal in its outlook.

\section{The Ocho poetas mexicanos anthology}

The epigraph to which Avilés referred, "[c]ada uno su lengua, todos en una llama," appears on an unnumbered page at the start of the anthology. It could be interpreted as an allusion to the flames of the Holy Spirit which enabled the disciples to speak other 
languages at Pentecost and so go on to spread the gospel (Acts 2: 1-4 AV) making it a potentially important piece of evidence supporting an argument that they were a group of Catholic poets. There is no evidence to establish how the epigraph was understood by contemporary audiences. Avilés and Castro, however, both agree that it refers to the group’s shared love of poetry which united them without diluting their individuality.

An analysis of the anthology demonstrates that the poets do differ in form and content. If one were to try to identify a common strand it would be an interest in the natural world, often accompanied by a sense of awe and wonder at its beauty. This theme is significant because it places them firmly within the less studied "universal" strand of Mexican literature. Of the eighty two poems in the collection, twenty one could be interpreted as being about religion or containing allusions to religion. A few of the twenty one could be said to provide evidence of Catholic religious conviction while the others deal with fundamental questions raised by religion and spirituality or reveal an interest in pre-Hispanic religions.

As is to be expected, Avilés' poems show the most evidence of religious conviction although most of the anthologised poems are not explicitly religious. In "La búsqueda” the speaker is walking along when suddenly he sees "un Rostro claro en la mitad del cielo” (27). vi The speaker's experience recalls Paul's conversion on the road to Damascus (Acts 9: $3 \mathrm{AV}$ ). The importance of having faith is underlined in the second verse which alludes to the miracles of Jesus (Luke 5: 1-11 AV), and Jesus telling his disciples that they will be "fishers of men" (Mark 1:17 AV; Matthew 4:19 AV), as the speaker urges his interlocutor: "Echa la red a nombre de Quien sabes, / y la verás henchida / con el seguro brillo de los peces” (27). “La búsqueda” addresses fundamental 
issues about faith, doubt and how one can be sure that God will provide in times of need. However, the penultimate section of the poem reminds the interlocutor that the response from God is unlikely to come in verbal form:

Lo buscamos ayer en el camino; en silencio hablaba.

A la sombra de un árbol casi viento se nos pobló el silencio de miradas. (28)

The following stanza explains that the "miradas" came from the Holy Trinity who brought water for the thirsty travellers in the same way that Jesus' miracle provided sustenance for the fishermen: "y Tres los que traían / para la sed el agua” (28). In the last section, the speaker acknowledges God's omnipotence saying that to Him alone belong the elements fire, air and water. However, the speaker concludes, the earth belongs to him as it is there that God's hands wait for him when he dies and is buried: "Mas para mí la tierra / donde Tus manos, oh Señor, / me esperan” (28). An interpretation of "La búsqueda” as a poem which emphasises the importance of faith and the search for God who will only reveal Himself at the moment of death is quite persuasive. Similarly, "Bendición de la casa” is about the way in which God watches over his disciples, although there is no explicit reference to God, only to "la gracia" (17). The religious significance of the poem is, therefore, more veiled than in "La búsqueda" and it is only by viewing "Bendición de la casa” through the prism of "La búsqueda," in which travellers who become aware of the presence of the Holy Trinity feel the silence suddenly populated with "miradas," that the following lines can be seen to allude to the idea that the Holy Trinity watches over the faithful:

Un amor como lluvia

de miradas

pone ojos en las cosas 
de la casa. (17)

A third example of Avilés' religious poetry is "Con nada menos," in which the speaker tells God about the difficulties faced by the people that He has chosen to love and to be His disciples:

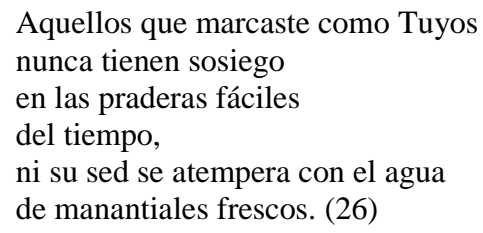

As in "Bendición de la casa," God is not mentioned directly but is instead identified by the use of the capital "T" in "Tuyos." However, not all of Avilés' poems are explicitly about religion even if they do allude to God. For instance, in the poem “iBorracho!” the speaker wonders about the fate of a drunk man whom he had seen shouting at himself and crying "Dios." The speaker says that he could find evidence of God's presence in the man's eyes (23).

Perhaps most surprisingly given his religious beliefs, Avilés also occasionally uses religious imagery in secular, and therefore profane, contexts. For example, in the poem "Soledad" the speaker uses striking metaphors to describe a saintly woman whose hands, although work worn and showing veins, are compared to the "temblor de aceite en vela / y dulzura de pan que se bendice” (24). The comparison, in keeping with a longstanding poetic convention, elevates human love to the level of the divine. Furthermore, there are also a number of Avilés' poems which do not employ religious imagery in situations where we might expect him to do so. In "Tránsito," the speaker imagines the day when his friends will carry him in a coffin to be buried, yet his view of death is not ostensibly a religious one. Instead, the poem expresses the speaker's gratitude to his 
friends and reflects that they and life, represented in the poem by nature, will continue without him:

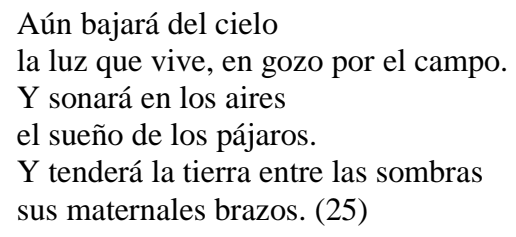

Despite containing no religious imagery or reference to God, this poem has been interpreted as having a religious dimension by Francisco Prieto: "Este entrañable poema, que narra el Tránsito del cadáver del poeta al fondo de la tierra en la conciencia del descanso de su alma en el seno de Dios” (Unomásuno, August 6, 1998). Prieto’s insertion of God's presence in the poem is perhaps illustrative of the way in which biographical knowledge about poets and authors can influence interpretations of their work.

Another poem in the anthology which deals with religious issues - as opposed to just containing religious imagery - is “A manera de lámpara," by Novaro, which is dedicated to Efrén Hernández. The poem describes how God showed Himself to the speaker, after which God's light revealed "un mundo de amor / y de cierta esperanza. (136). “A manera de lámpara” portrays a conversion experience. Navarrete Maya (2002, 35) characterizes Novaro as "poeta religioso," but this was denied by Castro, who claimed that Novaro was "descreído.” Margarita Millán (cited in Robles 2005, 219), writing about Novaro’s daughter, the cinema director María Luisa Novaro Peñaloza, has said that the family was "nacionalista y liberal. Su padre provenía de una familia de inmigrantes italianos y fue maestro cardenista y simpatizante del socialismo y marxismo.” If Castro and Millán’s statements are accurate, the choice of subject matter may have been due to the poem's dedication to Hernández. Alternatively, the poem may 
be seen as revealing Novaro's desire to recover his lost faith as a result of a confirmation similar to that which the speaker receives. However, if this were the case, we might expect the poem to be written in the conditional or future tense rather than in the past tense, as if reflecting on an event which has actually occurred.

Novaro’s long poem "El cementerio de los árboles” is dedicated to his daughter: “A María Luisa, espíritu como árbol de poesía” (144). It revolves around a crisis of faith as well as the awareness of God's power to intervene (or not) in man's fate. The poem is also about death, loss, friendship and inter-generational relationships. The speaker imagines himself walking through a forest at sundown looking at the dead trees who are anthropomorphised so that they each have a personality. In the forest of dead trees, the speaker likens himself to the only tree left alive which not even the axe wanted to touch (150-1). In the fourth section, he laments the number of dead trees and draws on ideas about God's presence in nature. Thus, the speaker says that sometimes "el mismo Creador” is responsible for the death of trees, such as when thunder is sent as a warning followed by deadly lightening (147). As the next verse makes clear, however, God is also responsible for regeneration and rebirth: "los mansos aires son Sus manos / [ ...] / y deshojándonos los brazos / para que nazcan nuevos” (147). A further example of religious imagery is found in the fifth section of the poem in which the younger generation is represented by a "sauce adolescente," which is accompanied by an older priest-like cedar tree, the "solemne cedro sacerdotal" (148). The cedar tree has also been felled, but it seems to have died peacefully accepting its fate and atoning for its sins, which include being used as the wood for the cross of Christ:

Abrió sus poros a la podredumbre como buscando en ella 
la redención de su linaje

y, litúrgicamente,

cruzó las manos,

[...]

con el noble ademán de quien libera

una vieja alma de madera

del antiguo pecado de la Crucifixión. (148-9)

The poem ends with an exhortation to a surviving, martyr-like tree, which is likened to the tree to which Saint Sebastian was tied. This tree is urged to pray for the dead and for the speaker who confesses to having been an accomplice to the deaths of the other trees and to having a heart that is "culpable y fariseo" (155). The poem, therefore, includes much religious imagery and, as in “A manera de lámpara,” the speaker seems to lament his lack of faith but it is not exclusively, or even principally, about religious belief.

Having considered those poems which could be interpreted as dealing with religious issues, it is noteworthy that three points of commonality emerge: conversion experiences, crises of faith and the question of God's omnipotence and omnipresence. These are fundamental issues when it comes to religious belief but only Avilés’ poems could be said to provide evidence of religious conviction as the trust in God found in some of them is not found in those by Novaro.

Other poems in the anthology include religious images but are not about religion and do not provide evidence of religious conviction. As has been noted, religious imagery has long been part of poetic convention, especially in love poems such as those by Cabral del Hoyo and Peñalosa. In Cabral del Hoyo’s “Mientras enamorado” and in "En lugar de olvidarnos,” the speaker compares being in love to a miracle:

Mientras enamorado me recreo en el milagro de la dulce vida. (33)

¿No era lo nuestro amor? La fe más pura 
no obró mayor milagro, cuando hacía

de los cielos caer el pan del día,

manar el agua de la roca dura. (47)

Just as the speaker of Avilés' “Soledad” elevated and justified his love with reference to divine love, so, too, does the speaker of "En lugar de olvidarnos” by likening his earthly desire to the love that God requires from His disciples: “¿Pues cómo, siendo amor, a tal estado / pudo venir? ¡Dios quiere, lo primero, / sobre todas las cosas ser amado!” (47). Here, as in Avilés’ poem, religious imagery is used hyperbolically in profane contexts for poetic effect. Peñalosa likewise uses religious references in the context of secular love in "Luz de los júbilos” in which the speaker suggests that if the love between him and his interlocutor were to die "se nos escondería Dios, con los ojos tristes” (173). While the poems “En lugar de olvidarnos," “Luz de los júbilos” and “Mientras enamorado” use religious imagery as part of poetic convention, they do not endorse or advocate Catholic beliefs and so the anthologised poems alone do not provide enough evidence to justify labelling all of the Ocho poetas as Catholic poets.

The suggestion that the Ocho poetas were "poetas católicos" is further complicated by the contributions of Magaloni and Castellanos. Their poems contain evidence of what might be termed spirituality, but it is not exclusively or even primarily Catholic. Patricia Ortiz Flores claims that Magaloni “poetiza el amor, la fe cristiana y la muerte, sobre todo en su poemario 'Palabras en la muerte' en el que recrea nuevamente la noción de ella entre los antiguos Americanos” $(\mathbf{2 0 0 0 , 1 2 ) . ~ I n ~ t h e ~ f i r s t ~ p o e m ~ o f ~ P a l a b r a s ~}$ en la muerte, the speaker imagines dying in his mother's arms and leaving behind the suffering of the world. In death, the speaker believes that he will return to nothingness, “me vuelvo espacio” (116). Similarly, in Poem 11, the speaker imagines that he comes 
from and will be reunited with nature: “Nos juntaremos, árbol, piedra, hombre, / subiendo má allá de nuestras ramas, / [...] / Es que fuera del tiempo seremos uno mismo” (126-7). Poem 3 also emphasises the connection between human beings and nature as the speaker asks to return to the world like a tear in the water:

Que no se seque nunca la confianza de mis ojos:

y el día de la muerte,

esta gota de vida,

este cuento de niño

caiga como una lágrima en el agua. (118)

In these poems, the speaker longs to be reincorporated and reintegrated fully into the natural world. If man is to become part of nature after death, then, according to Mayan beliefs, he has a particular responsibility to nature. This view is expressed in Poem 12 which begins: “Como guardianes somos de las cosas que viven con nosotros” and continues to explain how people are temporary guardians of nature while they are alive (128). Thus, the view of man's place in the world and what happens to him after death that we find in Magaloni’s poems supports Castro’s assertion that the poet “tenía mucho interés por todo lo que fuera la cultura maya y hasta seguir con la religión de

Quetzalcóatl.”

Castellanos’ “Misterios gozosos” appears to juxtapose Christian imagery with Mayan beliefs. According to A. K. Stoll $(1987,48)$, this poem was first published in 1958 but its inclusion in the Ocho poetas anthology, published in 1955, means that we need to revise our dating of the poem. It includes references to God and "el Señor" who is the “ente masculino del centro de un universo alegre y eterno" (Stoll 1987, $\mathbf{5 8}$ ) to whom the speaker submits promising to sing hymns in his praise. Furthermore, stanza 9, which Stoll identifies as the “centro y clave del poema” $(1987,49)$, opens with the speaker comparing 
herself to Cain as someone who has received "un don precioso," that is, the gift of poetry, but recognises that she is responsible for looking after this gift as she will be accountable to God for what she has done with it (57). If she does not use the gift of poetry wisely, perhaps she, like Cain, will be punished. These references, however, are isolated in a poem which otherwise does not provide evidence of Catholic faith. Stoll explains Castellanos’ use of biblical references as follows:

La inclusión de Abel y Caín evocan [evocan sic] el cuento bíblico encontrado en Génesis del comienzo de la historia humana. Caín y Abel constituyen el arquetipo de los hermanos y prefiguran los problemas universales de origen humano, como la discriminación y la guerra, el único elemento negativo del poema. $(1987,55)$

She adds that it is "el cuento de uno que dirige nuestros pensamientos hacia el pasado arcaico" (Stoll 1987, 62). The God in the poem is not so much significant in His own right but as a counterpoint to the feminine mother earth. This blend of ideas has led Stoll to interpret "Misterios gozosos" as "una celebración de los sentimientos de la poetisa con respecto a la diversidad existencial. Es también un serio enunciado filosófico a base de arquetipos y una perspectiva propia de los mayas” $(1987,48)$. In support of her argument, Stoll claims that Castellanos was influenced by her study of philosophy and that the poet was knowledgeable about Mayan beliefs (1987, 48, 62). Thus, like the poems of Magaloni, Castellanos’ poem could be said to reveal an interest in religion and spirituality without being specifically Catholic in inspiration.

Reading the anthology as a whole, there is scant justification for labelling the group "Ocho poetas mexicanos católicos." The anthology includes only a few poems about religion and some religious imagery, but in the work of certain members of the group there is none at all. What is most striking about the anthology viewed as a whole is 
not the concern with religion, but the use of natural imagery and the emphasis on the beauty of the natural world which can be seen as part of an attempt to establish an alternative vision of "Mexican poetry." Castro’s poems in particular exemplify this focus on the natural world as a source of national pride which could form the basis of a uniquely Mexican poetic tradition. They describe rural settings, and the seasonal and diurnal changes in the environment. Her poems, with their frequent references to the wind, sun and water, often express a sense of awe and wonder at nature. Wind, which features in the title of her novel La ciudad y el viento (1962), is, according to Castro, "una imagen de lo que nos lleva” and a metaphor of forces which are beyond the speaker's control. This can be seen in "Yo no sé qué me lleva," entitled “Con los ojos abiertos" in Cantares de vela (Castro 1996, 61), in which the speaker is carried along by the wind, which is "más allá de mis ojos / y me dobla las fuerzas / como ramas" (80). The words “flor," "rama," "tierra” and “campo” also recur throughout Castro's poetry and two of her poems are about specific types of trees. "Savia que sube al pecho" (88) $)^{\mathrm{vii}}$ is about the fig tree, while "Nada sabe decir" (90), entitled "El huizache" in Cantares de vela (Castro 1996, 63), is about the huizache, a species of acacia. On the poems that she selected for inclusion in the anthology, Castro stated: "Elegí los que me parecían que eran más expresivos, no los que tuvieron el mismo tema ni nada. Entonces, eran poemas, me acuerdo, algunos sobre árboles... [...]?” About the huizache she said:

el huizache también es de una región desértica y que tiene unas florecitas amarillas, pero es como toda una necesidad de ser y de florecer, se me figura es el símbolo de México y de los mexicanos que como del lugar, sobreviven, sobrevivimos. (Emphasis added)

This comment clearly demonstrates that, for Castro, writing about nature was not just a way of dealing with "universal” themes or looking outwards but rather a way of writing 
about a specifically Mexican context and people. Thus, she explains, she saw the huizache tree as a metaphor for the rural poor: "hay un momento en que uno tiene ganas de decir no valemos la pena los mexicanos pero luego, sobre todo en provincia, llega uno y se da cuenta de que son la mayor parte de los mexicanos como las flores del huizache, salen de una pobreza espantosa." In "Nada sabe decir," the speaker refers to the huizache tree “en la mitad del llano” with its “[...] flor, / dorada / como el sol que le quema” (90). Having suffered the dry winter, the summer comes and renews the barren earth:

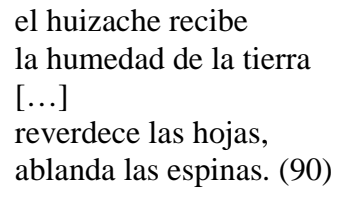

Finally, the small yellow flower appears and "canta toda la tierra” (90). In this powerful comment on the ability of the Mexican people to transcend their situation, hardship is overcome and replaced with hope represented by the huizache flower.

The poems of Castro, Cabral del Hoyo and Avilés all bear markers of their birthplaces. Cabral del Hoyo’s poems have rural settings and make frequent references to the wind. In "Contra el oscuro viento," the speaker compares his experience to that of plants through the changing of the seasons as he describes a rose bush waiting to emerge in spring after enduring wind, drought and icy conditions (48). Notably, the rose stands up to the north wind (cierzo). In "Cancioncilla," the speaker alludes to the difference between the smells and sounds of the wind from the land, as opposed to those of the wind that comes from the sea (42). Like Castro, Cabral del Hoyo was from Zacatecas, and as Castro explained, “allí tiene tal categoría el viento que de joven yo despertaba con el rumor del viento que pasaba a través de las rendijas de las ventanas pero aullando o 
cantando.” Equally significant, however, is the use of the image of a speaker blown by the wind to praise resilience in the face of external forces. Rivers, which feature prominently in Avilés’ poetry, including “Río” (14) and "Raíz del canto” (9-11), also connect to a specific Mexican context as the poet is from La Brecha, Sinaloa. He said: “en ocasiones me preguntan por qué en mi poesía aparece tanto la evocación de un río; y creo que es porque yo nací a la orilla de un río; todos los sinaloenses hemos nacido junto a un río porque por ese estado cruzan 11 ríos: ahí tienen $20 \%$ del agua nacional” (El Universal, September 25, 1984). Finally, while love is the principal theme of Peñalosa's poetry, it, too, is notable for its use of natural imagery as love is addressed "mediante imágenes en las que predomina la diafanidad y la transparencia del agua, el viento, la luz y el cristal, lo que recuerda a los místicos españoles” (Rubio Pacho 2002, 437). This common interest in nature and the fact that many of these poets were from outside Mexico City indicates that future work aiming to reassess their contribution could usefully examine it from a regional or even eco-critical perspective. This regional perspective is often overlooked in studies of Mexican literature as well as in official constructions of nationalism.

A close reading of the anthology Ocho poetas mexicanos shows that the Ocho poetas shared an interest in nature, in the different experiences of love (Cabral del Hoyo and Peñalosa), and a sense of wonder at the universe (Hernández), rather than a sole preoccupation with religion and the writing of religious poetry. This feature of their work is symptomatic of their alternative approach to producing a kind of poetry that was simultaneously "universal” and "Mexican" even though it was not recognised as such within the narrow parameters of official nationalism. Benjamín Barajas observes that 
Castro's work is a "meditación constante sobre el sentido de las palabras y sobre el acto de escribir como un proceso que permite descubrir y conocer el entorno cotidiano del hombre, así como su espíritu trascendente, a través de la concreción de los instantes de vida que representan experiencias vitales” (2010, 13-4). This characterization can be applied to all of the work in the Ocho poetas' anthology. Their poems, and especially those which are about the act of writing, such as Castellanos' "El resplandor del ser," make a case for not subordinating the aesthetic to the political at a time when art and literature were valued primarily as vehicles for political commentary.

\section{Conclusion}

The Ocho poetas were marginalised by a literary establishment that was hostile to outward-looking, "universal" literature and to Catholic authors. Some of the group members were Catholic while others were labelled as such by association. While some made overt reference to religious faith in the anthologised poems most did not.| Perhaps the original readers and critics struggled to categorise their work and so Catholicism became a label of convenience. Evidence from interviews and more recent newspaper articles suggests that the categorisation was based on external factors, assumptions or prejudices about the authors and their religious beliefs. The case of the Ocho poetas thus provides striking evidence of the way in which literature written by Catholics, or those assumed to be Catholic, was rejected in post-revolutionary Mexico even if they were not writing about religious beliefs. The experience of this group also highlights the way in which Mexican literary history and culture have prioritised a particular type of nation building in literature over literature that was either "universal" in outlook or presented 
alternative views of the nation. Despite the title of the anthology, these poets could not be considered "poetas mexicanos" in the cultural milieu of mid-century Mexico as their poetry did not address lo mexicano or mexicanidad in ways that were understandable or acceptable to the cultural elite. For this reason, as much as any other, the group members were marginalised and forgotten for much of the twentieth century and only now is their work beginning to receive the attention it deserves.

Acknowledgements: I would like to thank Edward Bowskill for his help in gathering and transcribing some of the archival material that was used in this article, and Professor Isabel Torres for reading and commenting on a draft of this article.

\section{Notes:}

${ }^{1}$ Unless otherwise stated, all quotations by Dolores Castro are taken from an interview with the author at Castro's home in Mexico City in September 2009. A transcript of the interview is available from the author on request.

${ }^{2}$ Castro also summarized the beliefs of the group in an interview with Benjamín Barajas (2004, 144) stating: “Octavio Novaro era anticlerical y de izquierda; Roberto Cabral del Hoyo, creyente, pero anticlerical; Honorato Ignacio Magaloni era creyente, anticlerical y de izquierda; Javier Peñalosa era católico, de izquierda y abierto a las corrientes nuevas. Efrén Hernández era creyente, pero no católico; Rosario Castellanos era católica de las fiebres terciarias y yo que soy católica, pero no mucho.” Further evidence of Castellanos’ changing beliefs can be found in an interview with Emmanuel Carballo in which she spoke of experiencing "una fuerte crisis religiosa" following the death of her parents as a result of which, she said, “dejé de creer en la otra vida” (Siempre, December 19, 1962). However, she continued, at the time when collection Poemas 1953-1955 was written, "[v]olví a una especie de religiosidad ya no católica, a una vivencia religiosa del mundo, a sentirme ligada a las cosas desde un punto de vista emotivo y a considerarl[a]s como objetos de contemplación estética” (Siempre, December 19, 1962). On the differing beliefs of group members, see Reforma, May 10, 1999.

3 On Avilés' involvement and eventual split with the PAN, see María Marván Laborde (1988, 197), Francisco Reveles Vázques (1999, 16, 19), and El Día, July 26, 1991.

${ }^{4}$ On Castro’s work at Radio Femenina, see Edna Aponte (2004).

${ }^{5}$ Ruiz Abreu hints at a shift in attitudes to Catholicism when he says "hasta fechas muy recientes, declararse católico en el ámbito intelectual en México era una ironía” (2003, 18; italics added for emphasis). This change can be seen in Vicente Fox's use of a banner of the Virgin of Guadalupe at a political rally during his successful presidential campaign in 2000 . 
${ }^{6}$ Unless otherwise stated, all subsequent references are to Alejandro Avilés, Roberto Cabral del Hoyo, Rosario Castellanos, Dolores Castro, Efrén Hernández, Honorato Ignacio Magalonia, Octavio Novaro and Javier Peñalosa (1955).

${ }^{7}$ As Castro's poems are not titled in the anthology, first lines are given in place of the title. The same poem is entitled "Herida" in the collection Cantares de vela originally published in 1960 (Castro 1996, 62).

8 The abbreviation 'CNL/EXP.Author's initials' refers to documents in the Centro Nacional de Literatura Archivo Hemerográfico de Escritores, Mexico City.

\section{References:}

Aponte, E. 2004. "Dolores Castro: la escritora de radio femenina.” In Raíz del agua. Textos en homenaje a Dolores Castro, edited by B. Barajas, 131-6. Mexico DF Ediciones del Lirio.

Avilés, A. 1996. “Palabras para un prólogo.” In Obras completas, edited by D. Castro, 9-20. Aguascalientes: Instituto Cultural de Aguascalientes.

Avilés, A., R. Cabral del Hoyo, R. Castellanos, D. Castro, E. Hernández, H. I. Magaloni, O. Novaro, and J. Peñalosa. 1955. Ocho poetas mexicanos. Mexico DF: Bajo el signo de “Ábside”.

Barajas, B. (ed.) 2004. Raíz del agua. Textos en homenaje a Dolores Castro. Mexico DF: Ediciones del Lirio.

Barajas, B. 2004. “Entrevista a Dolores Castro.” In Raíz del agua. Textos en homenaje a Dolores Castro, edited by B. Barajas, 137-53. Mexico DF: Ediciones del Lirio.

Barajas, B. 2010. “Presentación.” In Viento quebrado. Poesía reunida by D. Castro, 9-14. Mexico DF: FCE.

Barajas, B. “La reflexión en la poética de Dolores Castro.” Periódico de Poesía www.periodicopoesia.unam.mx [Accessed 25/08/11].

Brushwood, J. S. 1988. “Efrén Hernández y la innovación narrativa.” Nuevo Texto Crítico 1.1: 85-95.

Castro, D. 1962. La ciudad y el viento. Xalapa: Universidad Veracruzana.

Castro, D. 1996. Obras completas. Aguascalientes: Instituto Cultural de Aguascalientes.

Cervera, J. (n.d.) “Aquí la poesía Dolores Castro, corazón transfigurado.” CNL/EXP.DC. 
Cohn, D. 2005. “The Mexican Intelligentsia, 1950-1968: Cosmopolitanism, National Identity, and the State.” Mexican Studies/Estudios Mexicanos 21(1): 141-82.

González Garduño, B. 1991 (2 May). "Ricardo Cortés Tamayo Octavio Novaro fue un poeta verdadero a pesar de la conspiración del silencio.” CNL/EXP.ON.

González Salas, C. 1960. Antología mexicana de poesía religiosa. Mexico DF: Jus.

Harmon, M. M. 1972. Efrén Hernández: A Poet Discovered. Hattiesburg: University and College Press of Mississippi.

Hayes, J. E. 2000. Radio Nation: Communication, Popular Culture and Nationalism in Mexico 1920-1950. Tucson: University of Arizona Press.

Marván Laborde, M. 1988. “El Partido Acción Nacional (1949-1962).” Revista Mexicana de Sociología 50 (3): 189-99.

Murad, T. 1977-78. "José Revueltas and Beginnings of the New Narrative in Mexico.” Modern Language Studies 8 (1): 57-64.

Murguía Luna, P. 1993. “Los ocho poetas mexicanos. La madurez de la poesía moderna en México.” Tesis de licenciatura, UNAM.

Navarrete Maya, L. 1988. "Dolores Castro.” In Diccionario de escritores mexicanos siglo XX. Desde las generaciones del Ateneo y novelistas de la Revolución hasta nuestros días. Vol 1, edited by A. M. Ocampo, 348-9. Mexico DF: UNAM.

Navarrete Maya, L. 2002. “Octavio Novaro.” In Diccionario de escritores mexicanos siglo XX. Desde las generaciones del Ateneo y novelistas de la Revolución hasta nuestros días. Vol. 6, edited by A. M. Ocampo, 34-7. Mexico DF: UNAM.

Ocampo, A. M. 1988. “Rosario Castellanos.” In Diccionario de escritores mexicanos siglo XX. Desde las generaciones del Ateneo y novelistas de la Revolución hasta nuestros días. Vol. 1, edited by A. M. Ocampo, 333-43. Mexico DF: UNAM.

Ocampo, A. M. 1997. “Efrén Hernández.” In Diccionario de escritores mexicanos siglo XX. Desde las generaciones del Ateneo y novelistas de la Revolución hasta nuestros días. Vol. 4, edited by A. M.Ocampo, 51-4. Mexico DF: UNAM.

Olivares Zorilla, R., and A. Pereira. 1988. “Roberto Cabral del Hoyo.” In Diccionario de escritores mexicanos siglo XX. Desde las generaciones del Ateneo y novelistas de la Revolución hasta nuestros días. Vol 1, edited by A. M. Ocampo, 252-3. Mexico DF: UNAM.

Oropsea, S. 2003. The Contemporáneos Group: Rewriting Mexico in the Thirties 
and Forties. Austin: University of Texas Press.

Ortiz Flores, P. 2000. "Honorato Ignacio Magaloni.” In Diccionario de escritores mexicanos siglo XX. Desde las generaciones del Ateneo y novelistas de la Revolución hasta nuestros días. Vol. 5, edited by A. M. Ocampo, 11-12. Mexico DF: UNAM.

Pacheco, J. E. 1965. “Aproximación a la poesía mexicana del siglo XX.” Hispania 48 (2): 209-19.

Reveles Vázques, F. 1999. "Los intentos de institucionalización del Partido Acción Nacional (1956-1971).” Revista Mexicana de Sociología 61 (3): 3-24.

Robles, Ó. 2005. Identidades maternacionales en el cine de María Novaro. New York: Peter Lang.

Rosales y Zamora, P. 1987 (8 Jan.). "Novaro transformó el negocio de revistas.” CNL/EXP.ON.

Rubio Pacho, C. 2000. “Gabriel Méndez Plancarte.” In Diccionario de escritores mexicanos siglo XX. Desde las generaciones del Ateneo y novelistas de la Revolución hasta nuestros días. Vol. 5, edited by A. M. Ocampo, 24. Mexico DF: UNAM.

Rubio Pacho, C. 2002. “Javier Peñalosa.” In Diccionario de escritores mexicanos siglo XX. Desde las generaciones del Ateneo y novelistas de la Revolución hasta nuestros días. Vol. 6, edited by A. M. Ocampo, 437-8. Mexico DF: UNAM.

Ruiz Abreu, Á. 2003. La cristera, una literatura negada (1928-1992). Mexico DF: Universidad Autónoma Metropolitana-Xochimilco.

Sánchez Rebolledo, A. 1988. “Alejandro Avilés.” In Diccionario de escritores mexicanos siglo XX. Desde las generaciones del Ateneo y novelistas de la Revolución hasta nuestros días. Vol. 1, edited by A. M. Ocampo, 103-4. Mexico DF: UNAM.

Stoll, A. K. 1987. “Un análisis de 'Misterios gozosos’ de Rosario Castellanos.” Explicación de Textos Literarios 16 (1): 48-64.

Toledo, A. 2007. “Prólogo.” In Obras Completas I by E. Hernández, 9-18. Mexico DF: FCE. 
